April 2003 • NREL/CP-520-33965

\title{
Investigation of CdZnTe for Thin-Film Tandem Solar Cell Applications
}

\section{Preprint}

R. Dhere, T. Gessert, J. Zhou, S. Asher, J. Pankow, and H. Moutinho

To be presented at the 2003 Materials Research Society Spring Meeting San Francisco, California April 21-25, 2003

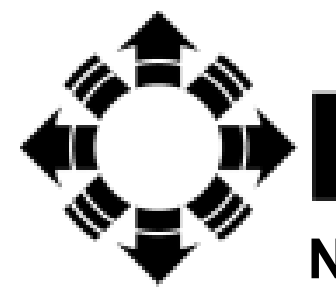

National Renewable Energy Laboratory

1617 Cole Boulevard Golden, Colorado 80401-3393

NREL is a U.S. Department of Energy Laboratory Operated by Midwest Research Institute $\bullet$ Battelle $\bullet$ Bechtel Contract No. DE-AC36-99-G010337 


\section{NOTICE}

The submitted manuscript has been offered by an employee of the Midwest Research Institute (MRI), a contractor of the US Government under Contract No. DE-AC36-99G010337. Accordingly, the US Government and MRI retain a nonexclusive royalty-free license to publish or reproduce the published form of this contribution, or allow others to do so, for US Government purposes.

This report was prepared as an account of work sponsored by an agency of the United States government. Neither the United States government nor any agency thereof, nor any of their employees, makes any warranty, express or implied, or assumes any legal liability or responsibility for the accuracy, completeness, or usefulness of any information, apparatus, product, or process disclosed, or represents that its use would not infringe privately owned rights. Reference herein to any specific commercial product, process, or service by trade name, trademark, manufacturer, or otherwise does not necessarily constitute or imply its endorsement, recommendation, or favoring by the United States government or any agency thereof. The views and opinions of authors expressed herein do not necessarily state or reflect those of the United States government or any agency thereof.

Available electronically at http://www.osti.gov/bridge

Available for a processing fee to U.S. Department of Energy and its contractors, in paper, from:

U.S. Department of Energy

Office of Scientific and Technical Information

P.O. Box 62

Oak Ridge, TN 37831-0062

phone: 865.576.8401

fax: 865.576.5728

email: reports@adonis.osti.gov

Available for sale to the public, in paper, from:

U.S. Department of Commerce

National Technical Information Service

5285 Port Royal Road

Springfield, VA 22161

phone: 800.553 .6847

fax: 703.605.6900

email: orders@ntis.fedworld.gov

online ordering: http://www.ntis.gov/ordering.htm

Printed on paper containing at least $50 \%$ wastepaper, including $20 \%$ postconsumer waste 


\title{
Investigation of CdZnTe for Thin-Film Tandem Solar Cell Applications
}

Ramesh Dhere, Tim Gessert, Jie Zhou, Sally Asher, Joel Pankow, and Helio Moutinho, National Renewable Energy Laboratory, Golden, CO 80401.

\begin{abstract}
Modeling of two-junction tandem devices shows that for optimal device performance, the bandgap of the top cell should be around 1.6-1.8 eV. CdZnTe alloys can be tailored to yield bandgaps in the desired range. In this study, we considered were used to fabricate these films, using close-spaced sublimation (CSS) and radio-frequency sputtering (RFS) techniques. In the first approach, we used mixed powders of CdTe and ZnTe as the source for film deposition by CSS. Even for the ZnTe/CdTe (95:5 ratio) source material, the deposited films were entirely CdTe due to higher vapor pressure of CdTe. In the second approach, we used pre-alloyed CdZnTe powders (CERAC, Inc.) as the source. Due to the lower sticking coefficient of Zn, even for the source composition of $75 \% \mathrm{Zn}$, these films contained very low quantities of $\mathrm{Zn}(\sim 5 \%)$. We tried unsuccessfully to increase the $\mathrm{Zn}$ content in the films by confining $\mathrm{Zn}$ vapor by enclosing the region between the source and substrate, reducing the substrate temperature to $400^{\circ} \mathrm{C}$, and adjusting the source/substance distance. Finally, we used thin-film couples consisting of 300-nm-thick CdTe deposited by CSS and 300-nm-thick ZnTe deposited by RFS; the samples were then heat-treated in cadmium chloride vapor. Compositional analysis of the samples showed extensive interdiffusion of $\mathrm{Cd}$ and $\mathrm{Zn}$ for the annealed samples. We will present the data on the various stack configurations of CdTe and ZnTe, the effect of different post-deposition anneals, the effect of oxygen on the interdiffusion and alloy formation and its possible correlation to the device performance degradation.
\end{abstract}

\section{INTRODUCTION}

Polycrystalline thin-film solar cells based on II-VI and I-III-VI compounds have been quite successful, with efficiencies of laboratory devices reaching $16.5 \%$ for CdTe [1] and 19.2\% for CIGS [2] single-junction solar cells. For further improvement, one needs to look at the tandem device option. Device modeling of two-junction tandem devices shows that the optimal bandgap of the top cell should be around 1.6-1.8 eV [3]. Ternary alloy CdZnTe is a good candidate as it is a well-behaved system and is based on CdTe.

In this paper, we use three key approaches that have been responsible for improved performance of CdTe devices: 1) CSS technique for the deposition of alloy layers because the best-performing CdTe devices have resulted from the films prepared by CSS at high deposition temperatures. 2) $\mathrm{CdCl}_{2}$ heat treatment, which is a crucial step for the fabrication of high efficiency CdTe devices. 3) We explored the use of oxygen during different stages on film properties because it is another essential component of high-efficiency CdTe device fabrication. One of the objectives of this work is to investigate the differences in CdTe and CdZnTe systems that could explain vast difference in the device performance of solar cells fabricated from these materials $[4,5]$. 


\section{EXPERIMENTAL DETAILS}

All the samples in this study were prepared on borosilicate glass $/ \mathrm{SnO}_{2} / \mathrm{CdS}$ substrates. Fdoped $\mathrm{SnO}_{2}$ films with a thickness of $0.5 \mu \mathrm{m}$ were deposited by chemical vapor deposition. $\mathrm{CdS}$ films $\left(85 \mathrm{~nm}\right.$ thick) were deposited by chemical-bath deposition at $90^{\circ} \mathrm{C}$. Films with a thickness of around $500 \mathrm{~nm}$ were deposited from a mixed powder source of CdTe and $\mathrm{ZnTe}$ and prereacted $\mathrm{Cd}_{\mathrm{x}} \mathrm{Zn}_{1-\mathrm{x}} \mathrm{Te}$ alloys with $\mathrm{x}$ values in the range of 0.25 to 0.75 (Cerac, Inc.) by CSS at substrate temperatures in the range of $400^{\circ}$ to $580^{\circ} \mathrm{C}$ in $\mathrm{He} / \mathrm{O}_{2}$ ambient. ZnTe films $(\sim 300 \mathrm{~nm}$ thick) were deposited by RF sputtering at $350^{\circ} \mathrm{C}$. Figure 1 is a cross-section of the samples used for the interdiffusion experiments.

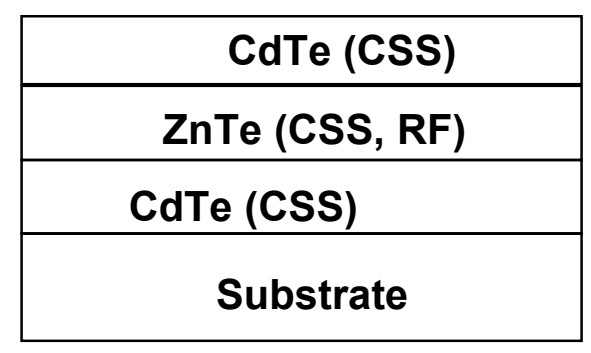

Figure 1. Cross-section of the samples used for interdiffusion studies

Post-deposition heat treatment of the samples was carried out at temperatures in the range of $400^{\circ}-440^{\circ} \mathrm{C}$ in the presence of $\mathrm{CdCl}_{2}$ vapor in $\mathrm{He} / \mathrm{O}_{2}$ ambient. Samples were analyzed using the following techniques: X-ray diffraction (XRD), atomic force microscopy (AFM), auger electron spectroscopy (AES) and secondary ion mass spectrometry (SIMS).

\section{RESULTS}

\section{Films deposited from CdTe/ZnTe powders and CdZnTe alloys}

Films deposited using mixed powders of CdTe and ZnTe for different deposition parameters mentioned below did not show the presence of $\mathrm{Zn}$, as measured by AES. This could be explained by the two factors: First, vapor pressure of $\mathrm{ZnTe}$ is almost an order of magnitude lower than CdTe in the source temperature range of $650^{\circ}-700^{\circ} \mathrm{C}$; second, both CdTe and $\mathrm{ZnTe}$ decompose in elemental form, and the sticking coefficient of $\mathrm{Zn}$ is considerably lower than $\mathrm{Cd}$ at substrate temperatures over $400^{\circ} \mathrm{C}$. We varied the source composition from a ZnTe:CdTe ratio of 1: 1 to 20:1 with no success in incorporating Zn.

To circumvent the problem due to the vapor pressure difference between CdTe and ZnTe, we fabricated films using pre-alloyed CdZnTe powder sources. These alloys were prepared by Cerac, Inc., by sintering the powders of CdTe and $\mathrm{ZnTe}$ at temperatures above $1000^{\circ} \mathrm{C}$. We confirmed that these alloys were single phase by XRD analysis. Although we have not measured the vapor composition, the deposition of a considerable amount of $\mathrm{Zn}$ on the cooler parts of the reactor during deposition indicates that the preformed alloys may be evaporating almost congruently. We did not see similar deposits when we used mixed powders of CdTe and ZnTe with similar $\mathrm{Zn}$ content in the source and identical deposition conditions. 
We varied the source temperature in the range of $640^{\circ}$ to $700^{\circ} \mathrm{C}$ and the substrate temperature from $400^{\circ}$ to $580^{\circ} \mathrm{C}$ and found out that the $\mathrm{Zn}$ content in the resulting films was always less than $5 \%$. Because there was a considerable amount of $\mathrm{Zn}$ evaporating from the CdZnTe alloy sources, we tried to confine the vapor by placing spacers on all four sides between the source and substrate. We did not see a noticeable increase in $\mathrm{Zn}$ content in the film. In the future, we will try to increase the partial pressure of $\mathrm{Zn}$ during deposition to increase $\mathrm{Zn}$ content in the films.

\section{Thin film couples of CdTe and ZnTe}

We attempted to form a CdZnTe alloy by interdiffusion of CdTe and ZnTe layers. We used the structure shown in Figure 1 for these experiments, where the substrate was borosilicate glass coated with $\mathrm{SnO}_{2}$ and CdS. Here, we present results on two types of samples: In the first, the top layers of $\mathrm{CdTe}$ were deposited at $580^{\circ} \mathrm{C}$ (HT sample) whereas in second sample, top layer of CdTe was deposited at $400^{\circ} \mathrm{C}$ (LT sample). In both cases, the bottom CdTe layer was deposited at $580^{\circ} \mathrm{C}$. We analyzed both as-deposited and $\mathrm{CdCl}_{2}$-treated samples. We show representative AFM images of as-deposited and $\mathrm{CdCl}_{2}$-treated samples in Figure 2.

As-deposited samples, grown at $580^{\circ} \mathrm{C}$, show the presence of boulders on the surface that disappear after $\mathrm{CdCl}_{2}$ heat treatment. We did not observe these structures on samples deposited at lower temperatures. The samples after $\mathrm{CdCl}_{2}$ heat treatment also showed a gradual increase in the grain size with increase in the temperature from $400^{\circ}$ to $440^{\circ} \mathrm{C}$ for both sets of samples.

AES depth profile spectra of HT samples before and after $\mathrm{CdCl}_{2}$ treatment are presented in Figures 3 and 4. Even though the top layer of the structure is $\mathrm{CdTe}$, we see intermixing of $\mathrm{Cd}$ and $\mathrm{Zn}$, as a result of high temperature deposition at $580^{\circ} \mathrm{C}$. We also see considerable concentration of oxygen in this sample, which is comparable to the quantity of $\mathrm{Zn}$ in the sample. Another interesting fact is that the profiles of $\mathrm{Zn}$ and $\mathrm{O}$ and of $\mathrm{Cd}$ and Te track each other. We also find diffusion of $\mathrm{Zn}$ and $\mathrm{Te}$ in the CdS layer, with slight diffusion of $\mathrm{S}$ in the CdTe layer. We do not see the distinct $\mathrm{CdTe} / \mathrm{ZnTe} / \mathrm{CdTe}$ structure for the as deposited sample in Figure 3.
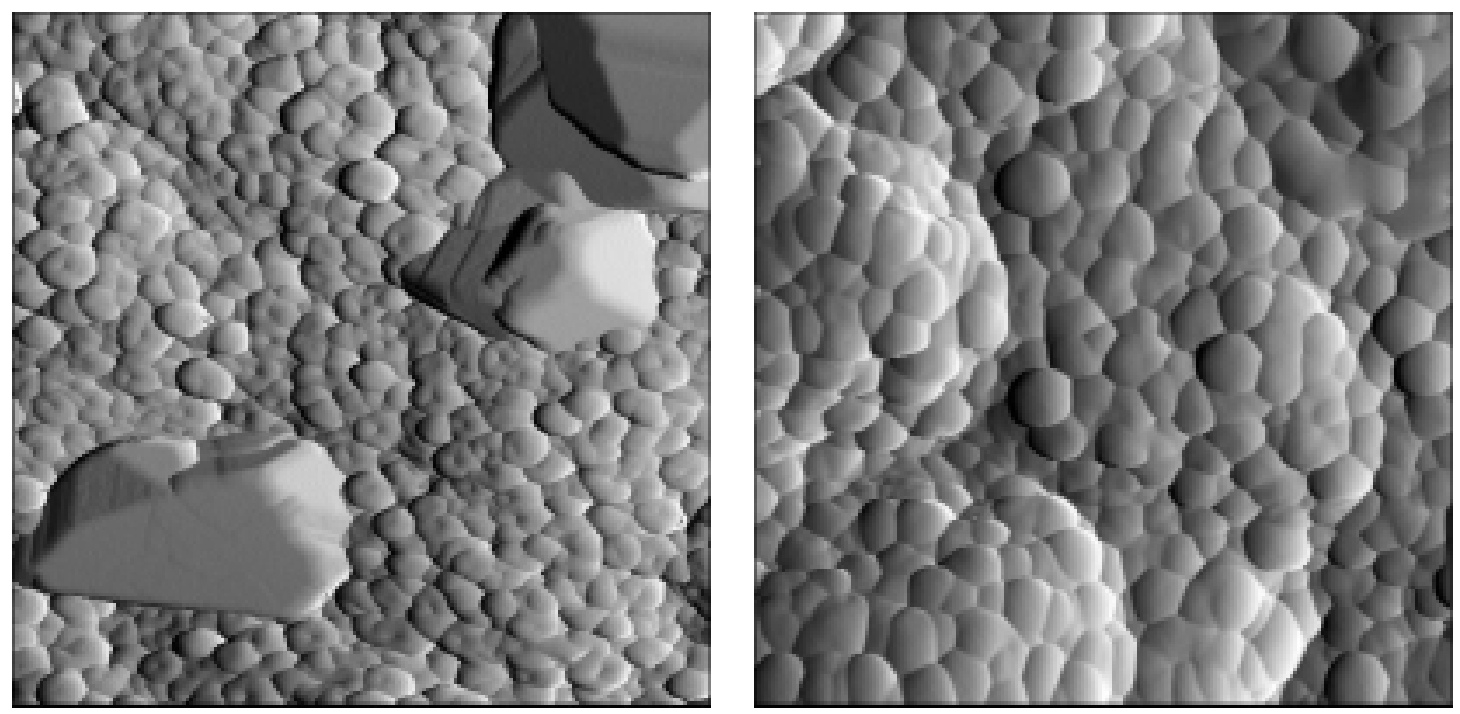

Figure 2. AFM $(1 \mu \mathrm{m})$ of as deposited (left) and $\mathrm{CdCl}_{2}$-treated $\left(440^{\circ} \mathrm{C}\right)$ samples. 


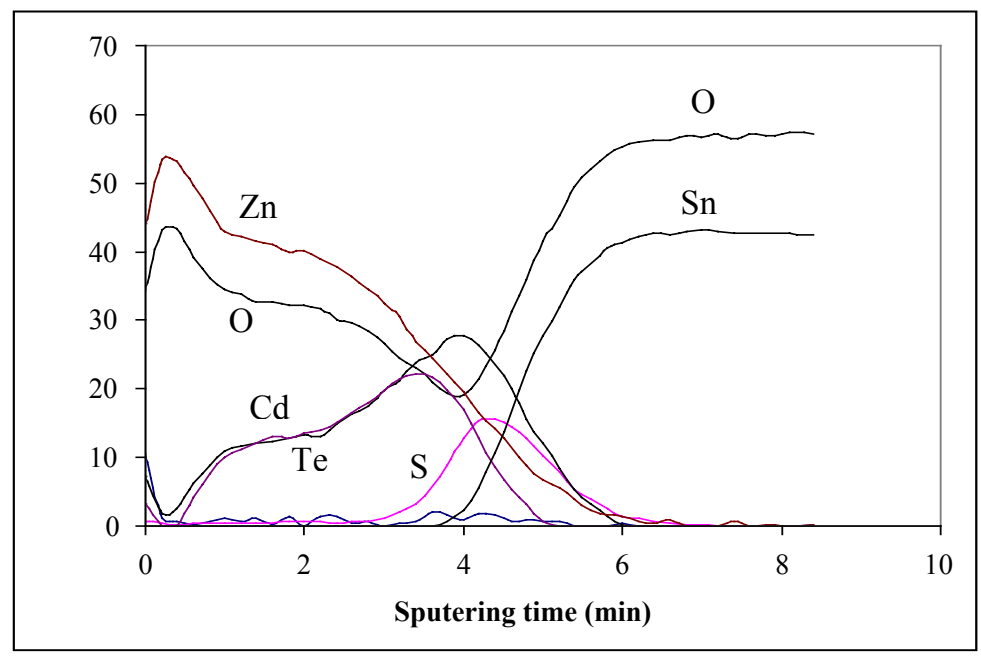

Figure 3. AES data for as-deposited HT sample.

After $\mathrm{CdCl}_{2}$ heat treatment (Figure 4), there is further interdiffusion, with $\mathrm{Zn}$ moving toward the front surface and the spreading of $\mathrm{Cd}$ and Te toward the center of the sample. We still see high concentration of $\mathrm{O}_{2}$ and the profiles of $\mathrm{Zn}$ tracking that of $\mathrm{O}$. We also see significant $\mathrm{Cl}$ concentration toward the front of the sample.

AES data for the LT samples are presented in Figures 5 and 6. Data for the as-deposited sample (Figure 5) shows a distinct 3-layer structure, which is completely different than the data for the HT sample (Figure 3).

In addition, the $\mathrm{Cd}$ spectra in the top and bottom layer exhibit different binding energies, implying different chemical bonding for CdTe deposited at $580^{\circ} \mathrm{C}$ (bottom layer) and $400^{\circ} \mathrm{C}$ (top layer). We see similar differences for Te in top CdTe layer and in ZnTe and bottom CdTe layers. The $\mathrm{Zn}$ spectra in the middle $\mathrm{ZnTe}$ layer have different binding energies compared to the interdiffused $\mathrm{Zn}$ in the top and bottom CdTe layers. AES data for the $\mathrm{CdCl}_{2}$-treated sample (figure 6) show extensive interdiffusion, with no signs of distinct layers. There is an

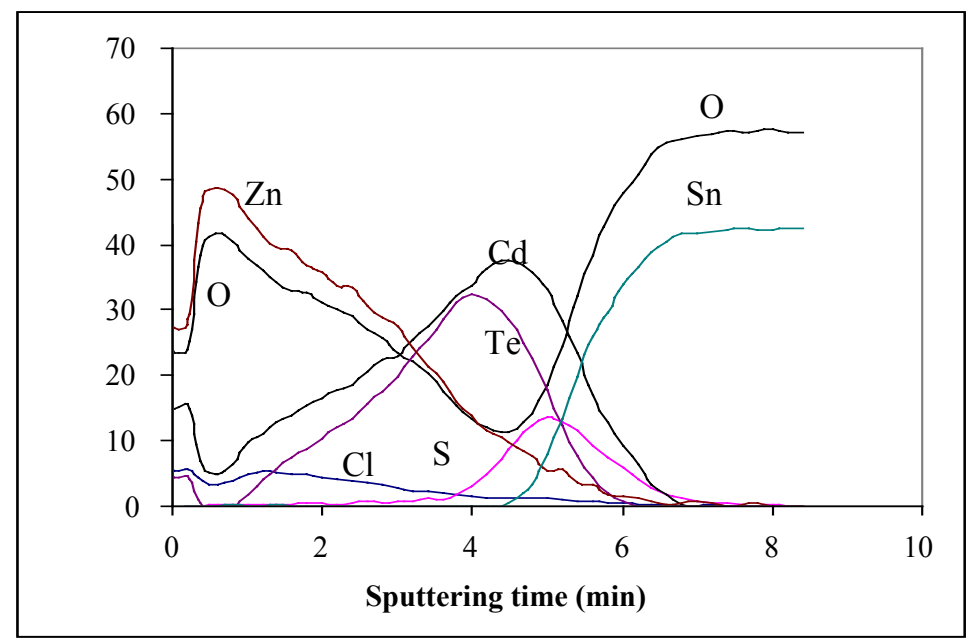

Figure 4. AES data for $420^{\circ} \mathrm{C} \mathrm{CdCl}_{2}$-treated $\mathrm{HT}$ sample. 


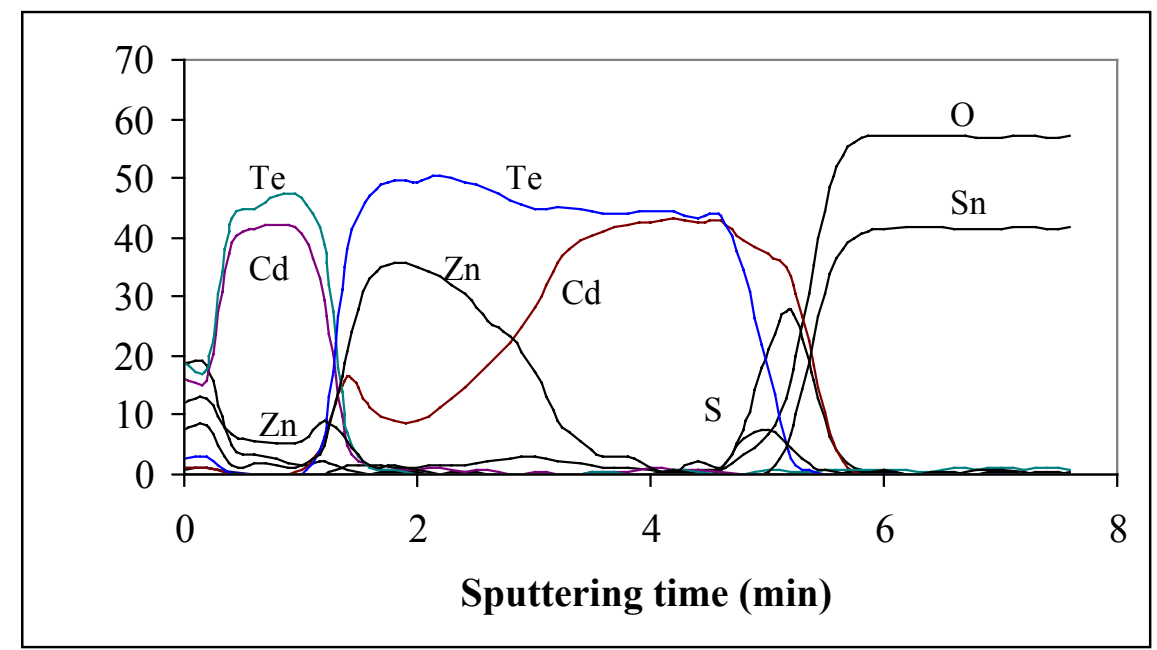

Figure 5. AES data for as-deposited LT sample.

accumulation of $\mathrm{Zn}$ in the front with a gradual decrease in the bulk of the film, tailing off at the CdS layer. This sample also shows behavior similar to samples deposited at higher temperature; the amount of oxygen in the layer is comparable to $\mathrm{Zn}$, and profiles of $\mathrm{Zn}$ and $\mathrm{O}$ have the same shape. In all the samples, we find S confined within the CdS layer in the substrate.

\section{DISCUSSION}

AES data presented here shows the effects of three factors: deposition temperature, $\mathrm{CdCl}_{2}$ heat treatment, and oxygen. The as-deposited LT sample shows limited interdiffusion, with clear demarcation of individual layers. The bonding energy of $\mathrm{Zn}$ in the $\mathrm{ZnTe}$ layer, deposited by RF sputtering in argon atmosphere, may be representative of $\mathrm{Zn}$ to Te bonding. The change of the bonding energy of $\mathrm{Zn}$ in the top and bottom CdTe layers, both of which are deposited in $\mathrm{O}_{2-}$ containing atmosphere, may be due to $\mathrm{Zn}$ bonded to oxygen. The $\mathrm{LT}$ sample after $\mathrm{CdCl}_{2}$

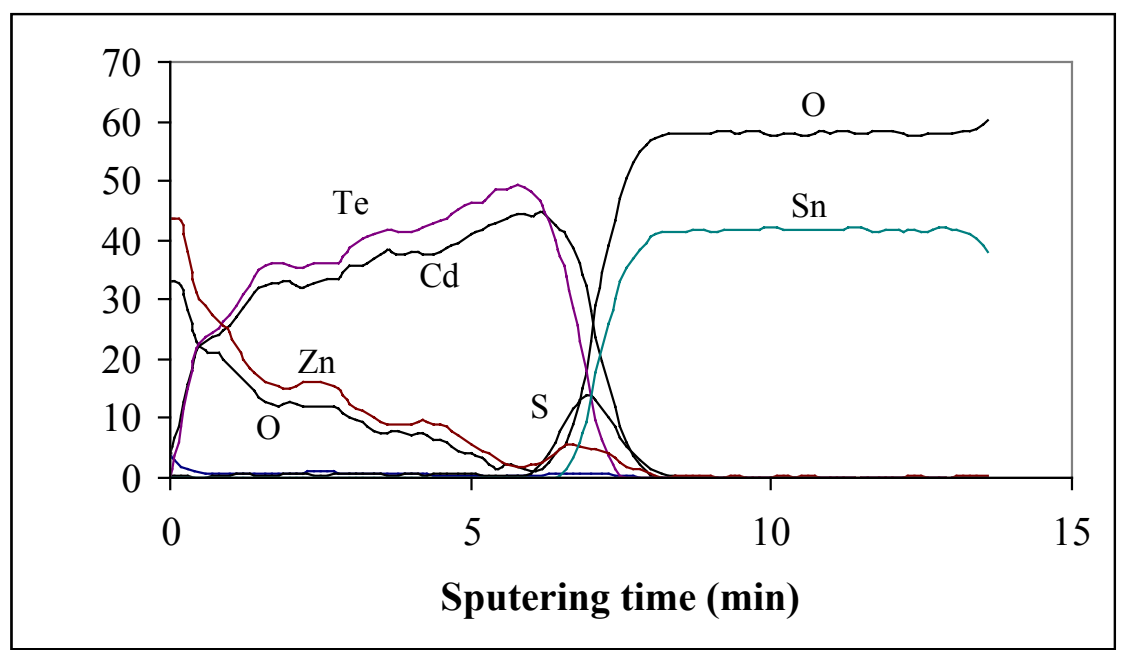

Figure 6. AES data for $420^{\circ} \mathrm{C} \mathrm{CdCl}_{2}$-treated LT sample. 
treatment in $\mathrm{He} / \mathrm{O}_{2}$ ambient at $400^{\circ} \mathrm{C}$ has similar $\mathrm{Zn}$ and $\mathrm{O}$ profiles indicating that all the $\mathrm{Zn}$ in this layer is bonded to $\mathrm{O}$ forming $\mathrm{ZnO}$. We also see $\mathrm{Cd}$ and $\mathrm{Te}$ profiles to be similar and the concentrations comparable to each other. This indicates that these are present as a CdTe compound. For the samples treated at higher temperatures, we find a gradual decrease in $\mathrm{Zn}$ concentration, with $\mathrm{Zn}$ and $\mathrm{O}$ having similar features. This may be due to the reaction between $\mathrm{Cl}_{2}$ and $\mathrm{ZnO}$, leading to the formation of $\mathrm{ZnCl}_{2}$, thereby losing $\mathrm{Zn}$ from the film. The HT sample shows the oxidation phenomena more distinctly. Here, even for as-deposited samples, we find an accumulation of $\mathrm{Zn}$ in front. Thus, during the high-temperature growth of CdTe on the $\mathrm{ZnTe}$ surface in oxygen ambient ( 1 torr $\mathrm{O}_{2} / 15$ torr $\mathrm{He}$ ), oxygen reacts with $\mathrm{ZnTe}$ at $580^{\circ} \mathrm{C}$, forming $\mathrm{ZnO}$. After $\mathrm{CdCl}_{2}$ heat treatment, we see further movement of $\mathrm{Zn}$ toward the front, as well as reduction in $\mathrm{Zn} / \mathrm{O}$ concentrations, again indicating the loss of $\mathrm{Zn}$ by $\mathrm{ZnCl}_{2}$ formation.

The results show that due to high affinity of $\mathrm{Zn}$ to oxygen, the presence of $\mathrm{O}_{2}$ during the deposition and/or postdeposition $\mathrm{CdCl}_{2}$ heat treatment results in the oxidation of $\mathrm{Zn}$. Even the small amount of oxygen during deposition (1 torr) is sufficient to oxidize all the $\mathrm{Zn}$, particularly at high temperature. Thus, the attempt to form the CdZnTe alloy is in fact producing a twophase mixture of CdTe and $\mathrm{ZnO}$. XRD results show the presence of two phases for the samples where we have seen significant $\mathrm{Zn}$ accumulation at the surface.

One can explain performance degradation of CdZnTe devices as compared to CdTe devices processed under identical conditions. During $\mathrm{CdCl}_{2}$ heat treatment in oxygen atmosphere, $\mathrm{Zn}$ is oxidized, resulting in a mixed layer of p-type CdTe mixed with n-type $\mathrm{ZnO}$ in the bulk. In addition, there may be an accumulation of n-type $\mathrm{ZnO}$ at the surface, forming a junction at the back contact that is opposing the main junction at the $\mathrm{CdS}$ interface.

\section{CONCLUSIONS}

Use of oxygen in any processing step of CdZnTe based devices results in oxidation of $\mathrm{Zn}$, thereby decomposing the alloy or preventing the of the alloy. The oxidation process is enhanced by high processing temperatures and $\mathrm{CdCl}_{2}$ ambient. $\mathrm{CdCl}_{2}$ vapor also leaches out $\mathrm{Zn}$ by the reaction with $\mathrm{Cl}$. The principal reason for the poor performance of present-day $\mathrm{CdZnTe}$ solar cells may be the result of using processing steps that work well for CdTe devices, but are inadequate for $\mathrm{CdZnTe}$ devices. The presence of $\mathrm{ZnO}$ in the absorber and the back contact of these devices can explain severe performance degradation. We need to develop oxygen-free device processing to improve device performance of $\mathrm{CdZnTe}$ devices.

\section{ACKNOWLEDGEMENTS}

We thank Dr. Xiaonan $\mathrm{Li}$ for $\mathrm{SnO}_{2}$ depositions and Mr. Bobby To for EPMA measurements. This work was supported under DOE Contract \# DE-AC-99GO10337.

\section{REFERENCES}

1 X. Wu et al., Proc. Of $17^{\text {th }}$ European PVSEC, p 995 (2001).

2 K. Ramanathan et al., to be published in Prog. In Photovoltaics (June, 2003).

3 T. Coutts et al., Technical Digest of $12^{\text {th }}$ PVSEC, p 277 (2001).

4 B. McCandless, Proc. Of $29^{\text {th }}$ IEEE PVSC, p 488 (2002).

5 T. Chu et al., J Appl. Phys. 71 (11), p 5635 (1992). 


\section{REPORT DOCUMENTATION PAGE}

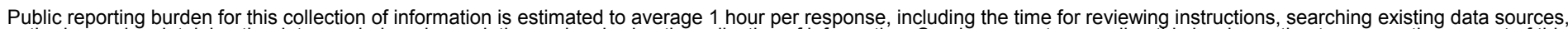

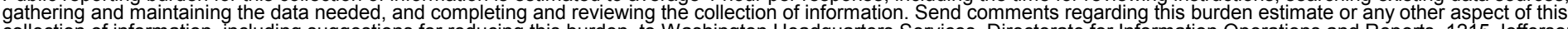

Washington Headquarters Services, Directorate for Information Operations and Reports, 1215 Jefferson Davis Highway, Suite 1204, Arlington, VA 22202-4302, and to the Office of Management and Budget, Paperwork Reduction Project (0704-0188), Washington, DC 20503.
1. AGENCY USE ONLY (Leave blank)
2. REPORT DATE
April 2003
3. REPORT TYPE AND DATES COVERED
Conference Paper

4. TITLE AND SUBTITLE

Investigation of $\mathrm{CdZnTe}$ for Thin-Film Tandem Solar Cell Applications

5. FUNDING NUMBERS

PVP34201

6. $\operatorname{AUTHOR}(\mathrm{S})$

R. Dhere, T. Gessert, J. Zhou, S. Asher, J. Pankow, and H. Moutinho

7. PERFORMING ORGANIZATION NAME(S) AND ADDRESS(ES)

National Renewable Energy Laboratory

1617 Cole Blvd

8. PERFORMING ORGANIZATION REPORT NUMBER

Golden, CO 80401-3393

9. SPONSORING/MONITORING AGENCY NAME(S) AND ADDRESS(ES)

NREL/CP-520-33965

10. SPONSORING/MONITORING AGENCY REPORT NUMBER

11. SUPPLEMENTARY NOTES

12a. DISTRIBUTION/AVAILABILITY STATEMENT

National Technical Information Service

12b. DISTRIBUTION CODE

U.S. Department of Commerce

5285 Port Royal Road

Springfield, VA 22161

13. ABSTRACT (Maximum 200 words) Modeling of two-junction tandem devices shows that for optimal device performance, the bandgap of the top cell should be around 1.6-1.8 eV. CdZnTe alloys can be tailored to yield bandgaps in the desired range. In this study, we considered were used to fabricate these films, using close-spaced sublimation (CSS) and radiofrequency sputtering (RFS) techniques. In the first approach, we used mixed powders of CdTe and ZnTe as the source for film deposition by CSS. Even for the ZnTe/CdTe (95:5 ratio) source material, the deposited films were entirely CdTe due to higher vapor pressure of CdTe. In the second approach, we used pre-alloyed CdZnTe powders (CERAC, Inc.) as the source. Due to the lower sticking coefficient of $\mathrm{Zn}$, even for the source composition of $75 \% \mathrm{Zn}$, these films contained very low quantities of $\mathrm{Zn}(\sim 5 \%)$. We tried unsuccessfully to increase the $\mathrm{Zn}$ content in the films by confining $\mathrm{Zn}$ vapor by enclosing the region between the source and substrate, reducing the substrate temperature to $400^{\circ} \mathrm{C}$, and adjusting the source/substance distance. Finally, we used thin-film couples consisting of 300-nm-thick CdTe deposited by CSS and 300$\mathrm{nm}$-thick ZnTe deposited by RFS; the samples were then heat-treated in cadmium chloride vapor. Compositional analysis of the samples showed extensive interdiffusion of $\mathrm{Cd}$ and $\mathrm{Zn}$ for the annealed samples. We will present the data on the various stack configurations of $\mathrm{CdTe}$ and $\mathrm{ZnTe}$, the effect of different post-deposition anneals, the effect of oxygen on the interdiffusion and alloy formation and its possible correlation to the device performance degradation.

14. SUBJECT TERMS

$\mathrm{PV}$; CdZnTe; tandem device; bandgap; close-spaced sublimation (CSS); radiofrequency sputtering (RFS); thin-film; couple; post-deposition anneal; interdiffusion; atomic force microscopy; X-ray diffraction (XRD); auger electron spectroscopy (AES); secondary ion mass spectrometry (SIMS);

17. SECURITY CLASSIFICATION OF REPORT Unclassified
18. SECURITY CLASSIFICATION OF THIS PAGE Unclassified
19. SECURITY CLASSIFICATION OF ABSTRACT Unclassified
15. NUMBER OF PAGES

16. PRICE CODE

20. LIMITATION OF ABSTRACT

UL 